solution, and when fertilization occurs in the presence of trypsin the hyaline layer is not formed ${ }^{6}$. It is unlikely, therefore, that the layer of extruded material has any affinities with the hyaline layer.

Experiments with crystalline trypsin and chymotrypsin gave no activation of the nuclei or of the surfaces of the Psammechinus eggs, and thus the results of previous workers have not been confirmed, at least in respect to this species.

The results with commercial trypsin show that activation is more comprehensive than was formerly thought, the activation involving the surface of the eggs as well as the nucleus. The destruction of the surface layers of the egg by the trypsin prevents, however, the possible expression of the surface phenomena associated with normal fertilization.

The negative results with crystalline trypsin and chymotrypsin indicate that the activating substance in commercial trypsin may be neither trypsin nor chymotrypsin, as was formerly supposed.

\section{Zoological Station,} Aage BoHus Jensen Naples.

June 24.

${ }^{1}$ Runnström, J., Ark. Zool., 40, A, No. 17 (1948).

2 Runnström, J., Monné, L., and Wicklund, E., J. Coll. Sci., 1. 421 (1946).

2 Monroy, A., Ark. Zool., 40, A, No. 21 (1948).

4 Hobson, A. D., J. Exp. Biol., 9, 69 (1932).

${ }^{5}$ Runnström, J., Protoplasma, 5, 201 (1928).

${ }^{6}$ Runnström. J.. Monné, L., and Broman, L., Ark. Zool., 35. A, No. 3 (1943).

\section{Soil Phosphate Uptake as Influenced by Phosphatic Fertilizer}

Perennial rye-grass was sown in small pots (12 cm. in diameter) on August 3, and harvested on October 22, 1947. Seven plants per pot were grown, and six replicate pots per treatment were provided. Two top soils from North Auckland Province, both very poor in available phosphate, were used. The Maunu loam derived from basalt is akin to a lateritic type; the Wharekohe silt loam, derived from an early tertiary claystone, is a mature podsol. They are classified respectively as "immature red brown loam" and "strongly podsolized yellow earth" by the New Zealand Soil Survey. Primary calcium phosphate labelled with radioactive phosphorus was used as fertilizer in amounts equivalent to $100 \mathrm{mgm} . \mathrm{P}_{2} \mathrm{O}_{5}$ per pot, this being roughly equal to a rate of 100 $\mathrm{kgm} . \mathrm{P}_{2} \mathrm{O}_{5}$ per hectare, calculated on an area basis. Dry-matter yields, total phosphorus and radioactivity were determined in the harvested plants.

The accompanying table gives some of the results obtained, the figures referring to sums of six replicates (pots). A full account will be published elsewhere.

\begin{tabular}{|c|c|c|c|c|}
\hline \multirow{5}{*}{$\begin{array}{l}1 \text { per cent citric acid soluble } \\
\mathrm{P}_{2} \mathrm{O}_{5} \text { per cent } \\
\mathrm{P}_{2} \mathrm{O}_{5} \text { added (mgm.) } \\
\mathrm{Y}_{\text {ields (tops and roots) in } \mathrm{gm} .} \\
\mathrm{P}_{2} \mathrm{O}_{5} \text { taken up by plants (mgm.) } \\
\text { From fertilizer }\end{array}$} & \multicolumn{2}{|c|}{ Maunu loam } & \multicolumn{2}{|c|}{ Wharekohe silt loam } \\
\hline & & & & \\
\hline & 0 & 600 & 0 & 600 \\
\hline & $0 \cdot 61$ & $8 \cdot 56$ & $0 \cdot 84$ & $13 \cdot 24$ \\
\hline & 0 & $37 \cdot 2$ & 0 & $95 \cdot 5$ \\
\hline $\begin{array}{l}\text { From soil } \\
\text { Total }\end{array}$ & $\begin{array}{l}1 \cdot 1 \\
1 \cdot 1\end{array}$ & $\begin{array}{r}3 \cdot \overline{3} \\
40 \cdot 5\end{array}$ & $\begin{array}{l}1 \cdot 65 \\
1.65\end{array}$ & $\begin{array}{r}14 \cdot 5 \\
110 \cdot 0\end{array}$ \\
\hline
\end{tabular}

Thus plants that received the phosphatic fertilizer took up three to eight times as much $\mathrm{P}_{2} \mathrm{O}_{5}$ from the original soil phosphate as the controls.

This experiment was finished when there came to hand a paper by Spinks and Barber ${ }^{1}$, who, using a radioactive tracer technique, obtained similar results with wheat. The occurrence of this phenomenon can thus be accepted as well established.
To my knowledge, the first hint that phosphate fertilizer might in some circumstances stimulate the uptake of phosphorus from the soil came from Leopold Zaleski (the paper appeared probably in the twenties, but unfortunately at the moment I am not able to give a more exact reference). In his experiments small doses of superphosphate placed beneath oat seeds increased the phosphorus uptake by more than the amount of phosphorus contained in these small doses, thus giving an apparent rerecovery or utilization of more than 100 per cent. Without a tracer technique, however, it would not have been possible to prove a stimulating effect of this kind in conditions less definite than those of Zaleski's experiment.

\section{Soil Bureau,}

K. StRzemieńskI

Department of Scientific and Industrial Research, Wellington, New Zealand. June 15.

${ }^{1}$ Spinks, J. W. T., and Barber, S. A., Sci. Agric., 28, 79 (Feb. 1948).

'Zaleski, L., "Superphosphate as Growth Stimulus", Mém. Inst. Pol. d'Econ. Rurale a Pulawy (in Polish).

\section{A Simple Apparatus for Adding Seitz-Filtered Components Aseptically to Embryo Culture Media}

IN attempting to culture excised immature plant embryos, it is frequently desirable to avoid autoclaving the nutrilite components (for example, malt extract). These are usually Seitz-filtered separately and transferred by pipette to the individual culture vials containing the previously autoclaved sugar and inorganic components of the medium. To workers unskilled in bacteriological methods, this represents a tedious and time-consuming operation.

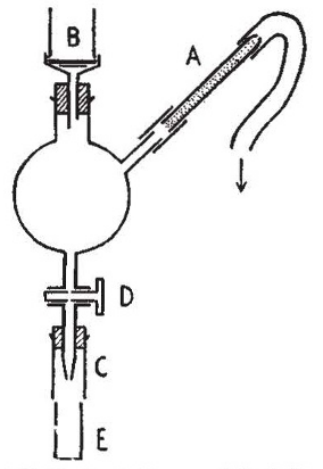
flter ; $(C)$ glass shield; $(D)$ stop-cock; $(E)$ culture vial
(A) Bacterial trap; (B) Seitz

The apparatus illustrated is simpler to handle and satisfactorily avoids contamination. Essentially it consists of a separatory type funnel with side vent to which can be attached a simple bacterial trap $A$, namely, a glass tube with one end partially closed, filled with loosely packed cotton-wool. The apparatus is autoclaved before use, the apertures at $B$ and $C$ being plugged with cotton-wool, and the stop-cock $D$ closed. During filtration, suction is applied through $A$, the partially sealed orifice preventing withdrawal of the contents of the trap. After filtration, the sbield $C$ is unplugged and the requisite number of drops (previously calibrated) added to the culture vials through the stop-cock $D$. The diameter of the shield should be slightly greater than the diameter of the culture vials $E$, which can then be inserted as illustrated while the filtrate is added. The bacterial trap $A$ allows air to pass into the apparatus without contaminating the filtrate as the latter is withdrawn.

Department of Agronomy,

S. G. Stephens

Texas Agricultural Experiment Station, College Station, Texas. July 6. 